(MOJEM)

April 2020, VOLUME 8, ISSUE 2, 44-58

E-ISSN NO: $2289-4489$

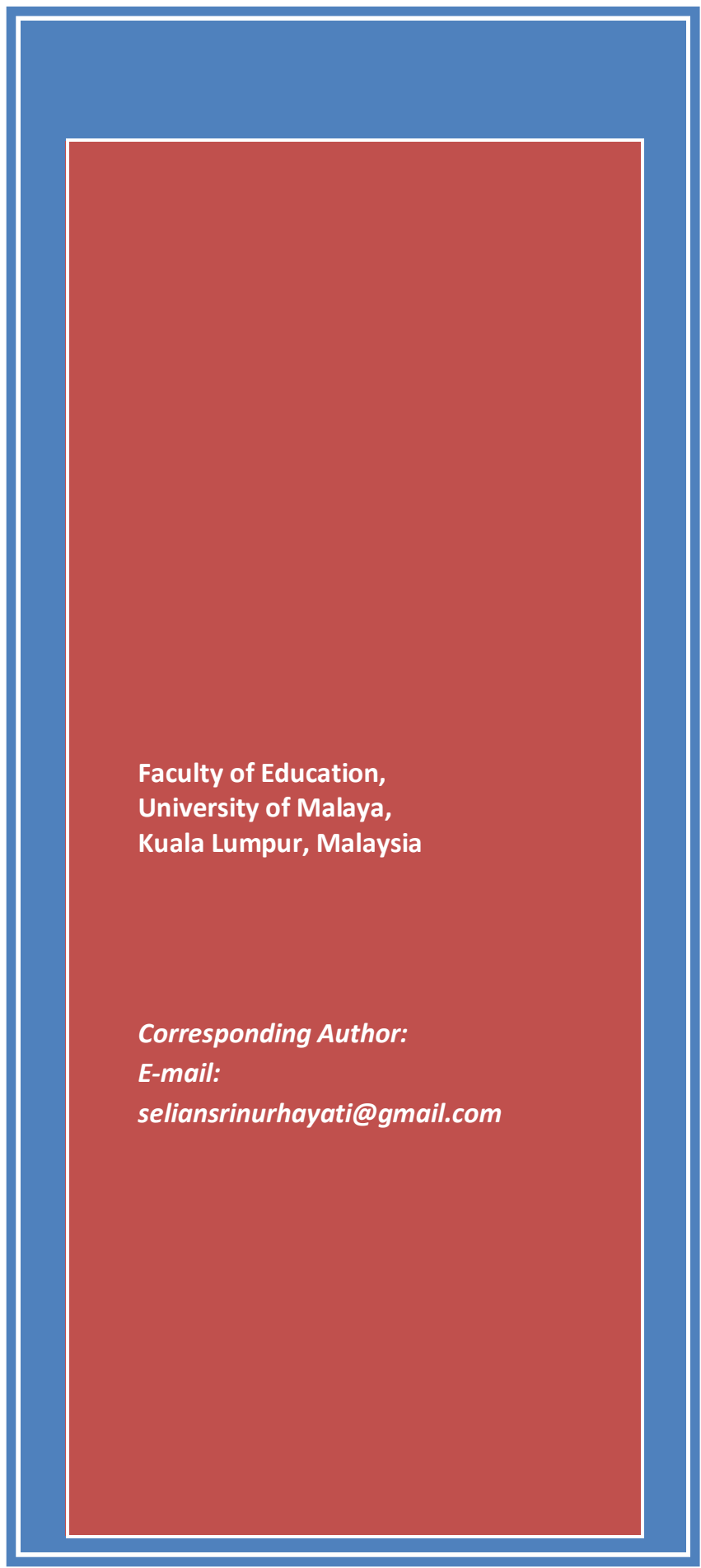

\section{FACTORS AFFECTING PSYCHOLOGICAL WELL BEING AMONG POSTGRADUATE STUDENTS UNDER INDONESIAN MINISTRY OF EDUCATION SCHOLARSHIP}

Sri Nurhayati Selian, Noor Aishah Rosli (PhD), \& Fonny Dameaty Hutagalung (PhD)

\begin{abstract}
Issue concerning academic stress, coping and social cultural adaptation among university students has driven to the need of deep understanding about factors that affect their psychological well-being. A correlational research design was used in this study. The researcher used two softwares to analyze the study data, namely IBM SPSS Statistics 23 and SmartPLS 3 (Partial Least Squares). The numbers of respondents in this study were 424 people. The sample determination in this study was using a simple random sampling technique. This study identified the influence of academic stress factors, coping and social cultural adaptation on psychological well-being of Indonesian postgraduate students, as well as produced a conceptual model that correlates between independent variables and dependent variable in this study. Thus, it can be concluded that academic stress, coping and social cultural adaptation have a significant influence on the psychological well-being of Indonesian postgraduatestudents. Hopefully, the results of this study can significantly contribute to the management of higher education, educators and professional counselors to pay more attention to the issue of academic stress experienced by postgraduate university students.
\end{abstract}

Keywords: Academic Stress, Coping, Social Cultural Adaptation, Psychological Well-Being, Ministry of Education, Indonesia 


\section{MALAYSIAN ONLINE JOURNAL OF EDUCATIONAL MANAGEMENT (MOJEM)}

\section{INTRODUCTION}

Currently, the world of higher education has undergone an academic revolution and many students have access to higher education (Badan Pusat Statistik, 2017). Statistical data on college growth (public and private universities) in Indonesia and the number of students enrolling in the universities are increased. During the 2014/2015 intake session, the number of public universities registered has increased by $18 \%$ and the number of students registering increased by $8 \%$ (Badan Pusat Statistik, 2017). As a result, many students studying at universities will face various pressures.

Significantly, students have been found more vulnerable to academic stress and is also more likely to suffer from stress whether they are undergraduate or postgraduate students (Feld, 2011; Friedlander, Reid, Shupak, \& Cribbie, 2010). Some studies have shown that $90 \%$ of university students experience significant stress (Feld, 2011; Kadapatti \& Vijayalaxmi, 2012; Thurber \& Walton, 2012). Universities are unique environments that often require students to balance their various roles and responsibilities. Academic stress occur when students cannot balance between their academic activities, social, emotion and family. Some researchers found that college students experience high stress due to academic commitment (Sansgiry \& Sail, 2006), social and family relationships (Desmita, 2009), finances (Andrews \& Wilding, 2004), daily complexity, lack of time management (Harikiran, Srinagesh, \& Nagesh, 2012), time demands, and new responsibilities (Aselton, 2012; Jdaitawi, 2015). If that does not work, the student will be stressed easily. Uncontrolled stress that exceeds a certain level will create various problems in individuals (Romas \& Sharma, 2004) such as, prolonged stress and excessive depression.

Some studies have reported that there is a relationship between academic stress and university students (Friedlander et al., 2010; Thurber \& Walton, 2012; Yusoff, Rahim, \& Yaacob, 2010). Some of the reasons that causes students to experience stress are due to disturbed family dynamics, pressure from other students, inability to cope with studies, drug abuse and lack of competence. The students also face a lot of stress due to imbalance of academic, social performances and time management for extra-curricular activities from education. Suriani and Suraini (2005) stated that university students are often faced with the stress of undergoing academic life such as the burden of duties given by lecturers, depressed college situations, personal adjustment problems with friends and the environment, conflicts and competition in the academic achievement. The findings of Suriani and Suraini (2005) are also supported by other research reports as conducted by Yeh and Inose (2003), they found that adapting to new situations and environment is not easy for students, especially if the difference between foreign countries and their home countries is very large (regarding the social and culture). This problem may add stress to the students who study outside abroad and students who study outside their home area.

Another example of studies using Indonesian students as their respondents in academic stress research by Suwartika, Nurdin, and Ruhmadi (2014), found that as many as $55.8 \%$ of students experienced overwhelming academic stress and most of the respondents in their research who experienced academic stress were females. In another study that is conducted by Huriatul, Pragita, Dani, Fifia, and Darmawi (2016) found that female students (41.0\%) had a higher number on academic stress compared to the men (28.8\%). Greer and Brown (2011) explained that stress will have a negative impact if the individual unable to cope with the stress that they faced and it can influence the individual's thinking as well as behaviour.

Students who experience academic stress will respond to their stress in different ways (Triantoro, 2006). Greer and Brown (2011) explained that stress will have a negative impact if the individual cannot overcome stress. However, some researchers said that when individuals were faced with stressful situations, they will try to overcome it both positively and negatively, which is called coping strategies (Greer \& Brown, 2011; Hoggard, Byrd, \& Sellers, 2012; Lazarus, 1966; Lazarus \& Folkman, 1984; Rice \& Van Arsdale, 2010; Somerfield \& McCrae, 2000). In Lazarus and Folkman's theory (1984), two coping strategies will be chosen and used by individuals such as problem-focused coping or emotion-focused coping. A person who is successful in using the coping strategies when he experiences 


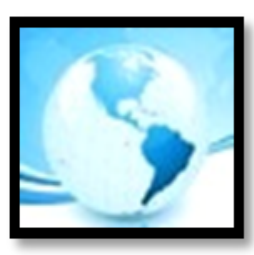

\section{MALAYSIAN ONLINE JOURNAL OF EDUCATIONAL MANAGEMENT (MOJEM)}

stress then he will have good well-being, e.g. physical and psychological well-being (Dzokoto, Hicks, \& Miller, 2007; Natovova, \& Chylova, 2014; Sri Nurhayati Selian \& Siti Rafiah Abdul Hamid, 2016).

Earlier research shows that self-reported stress is related with the presentation of anxious situations and lower well-being and stress is also the most important factor associated with students' psychological well-being because well-being can determine and predict academic achievement (Carter, Garber, Ciesla, \& Cole, 2006; Dzokoto, Hicks, \& Miller, 2007). A systematic review of some studies presented that in folks undertaking higher education, selfreported levels of stress are linked with poorer quality of life and well-being and some studies have shown that students wishing to have better results in relationships should have a high level of well-being (Borrello, 2005; Lyubomirsky, King, \& Diener, 2005). This is because a person who has psychological well-being is able to control the stress well (e.g. being able to arrange the schedule well though the activities in the classroom are very crowded), have a high level of self-esteem (a healthy body when doing all class activities), have emotional intelligence and ability producing quality work (Diehl \& Hay, 2011; Natovova \& Chylova, 2014; Myhren, Ekeberg, \& Stokland, 2013; Sagone \& De Caroli, 2014). Therefore, the topic of academic stress, coping, social-cultural adaptation, and psychological well-being among Indonesian students is very interesting to explore and this study is analyzed using SPSS Software.

\section{THEORETICAL FOUNDATION}

There are three theoretical frameworks used in this study; 1 ) The transactional model of stress and coping/TMSC by Lazarus and Folkman (1984), 2) The social-cultural adaptation of Searle and Ward/SCAS (1990), and 3) Six dimensions positive psychology/PWB developed by Carol Ryff (1989). Nevertheless, there were four main variables in this study, three of them were independent variables (such as academic stress, coping, socio-cultural adaptation) and the last one was a dependent variable (psychological well-being).

Furthermore, academic stress (ASS) in this study involved three sub-constructs namely physical stress (SF), psychosocial stress (SPK) and psychological stress (SPS). The second variable was coping or COPE, COPE consisted of three sub-constructs, namely problem-focused coping (PFC), emotion-focused coping (EFC) and the last one was coping responses are less useful (LCR). The third variable was socio-cultural adaptation (SCAS), divided into five sub-constructs namely making friends (AKB), participating in social gatherings (APS), using transportation (AMP), communicating with host nationals (AKW) and shopping (ABB). The last variable was psychological well-being (PWB) consisting of six sub-constructs namely autonomy (KPA), environmental mastery (KPS), personal growth (KPP), positive relations with others (KPH), self-acceptance (KPK) and purpose in life (KPT). Figure 1 below was a priori model of the proposed research model in this study. 


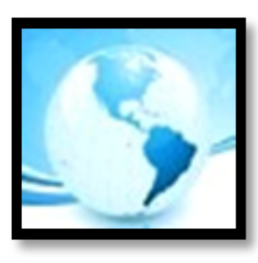

(MOJEM)

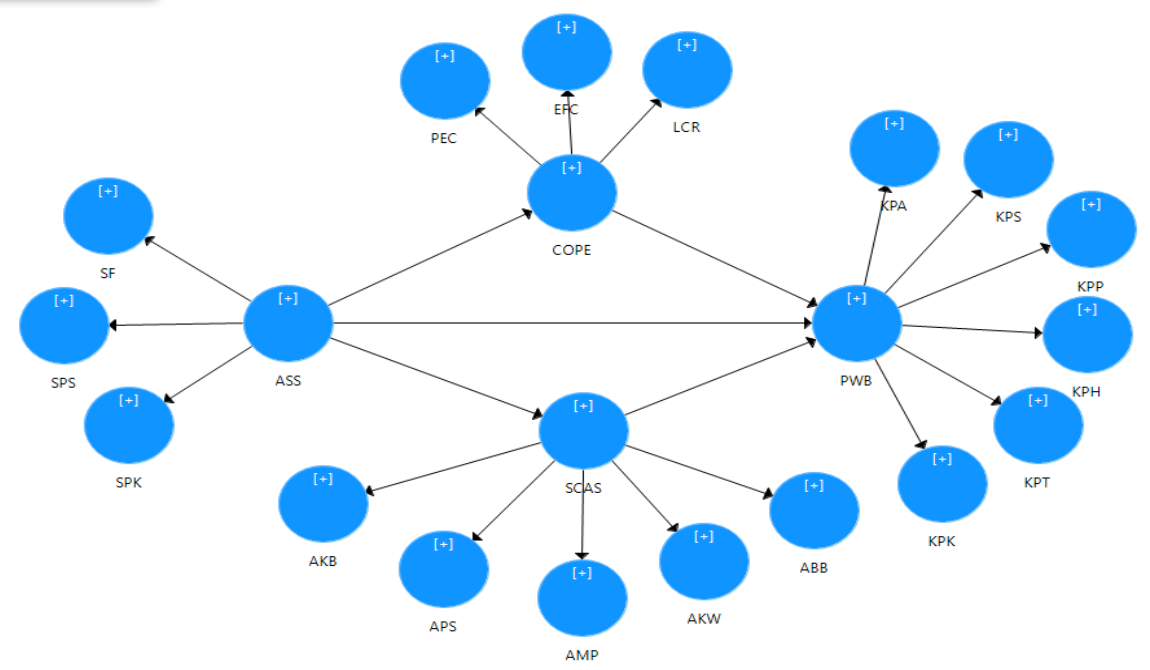

Figure 1. A priori model in the proposed research model

The two main research questions of this study are as follows:

1. Do academic stress, coping and social cultural adaptation have a significant effect on the psychological well-being among postgraduate students sponsored by Indonesian education?

2. Does academic stress have a significant effect on coping and social cultural adaptation of among postgraduate students sponsored by Indonesian education?

\section{METHOD}

The research has identified academic stress, coping, socio-cultural adaptation, and psychological well-being among Indonesian students. Below is a brief description of research design, population and sampling, research instruments and procedure.

\section{Research Design, Population and Sampling}

A correlational research design was used in this study. The researcher used two software to analyze the study data, namely IBM SPSS Statistics 23 and SmartPLS 3 (Partial Least Squares). The population in this study was Indonesian students whose studies are sponsored by Indonesia Endowment Fund for Education (they are studying masters and doctoral degrees, aged between 23 and 47 years). The numbers of respondents in this study were 436 people. However, after some data was deleted, the overall data was reduced to 424 as 12 outliers were identified. The sample determination in this study was by using a simple random sampling technique.

\section{Research Instruments}

To conduct this study, the researchers used questionnaire instruments that were relevant to the objectives and research questions and those instruments have been developed by previous researchers. Johnson and Christensen (2008) stated that the questionnaire is a research measure in the form of a self-report which is completed by the respondents of the study as part of the research. 


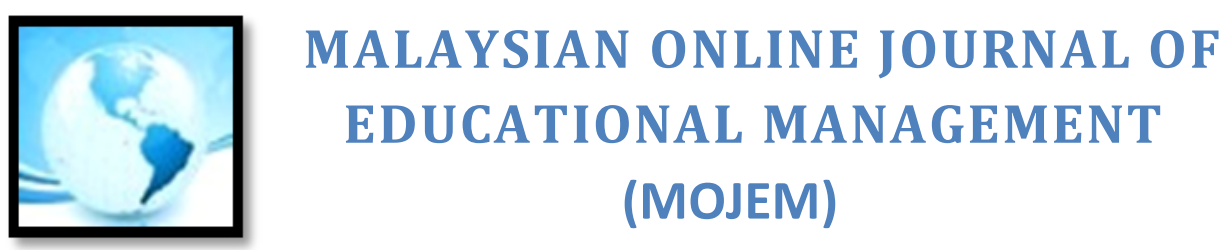

- The Academic Stress Scale (ASS)

The Academic Stress Scale (ASS) developed by James Kohn and Gregory Frazer in 1986 was used to collect data in this study. The ASS consists of 35 items on a 5-point Likert scale and it was designed to measure the source of student academic stress. Previous studies (Burnett \& Fanshawe, 1997; Kohn \& Frazer, 1986) found good internal reliability for the whole scale $(\alpha=0.92)$ and for each sub-scale and factor $(\alpha=0.73-0.84)$.

- The Coping Orientations to Problems Experienced Inventory (COPE)

The Coping Orientations to Problems Experienced Inventory (COPE; Carver, Scheier, \& Weintraub, 1989) has 60 question items that measure the value of coping. Respondents were asked to choose an answer based on their experience in coping on a 4-point Likert scale. Litman (2006) reported that the alpha coefficient of COPE in the results of his study as .73 and .75 for the second alpha coefficient. Then, Mitchell (2016) reported Cronbach's alpha for the COPE scale in his study of .859. Thus, the reliability value of the COPE instrument has met the validity and reliability aspects.

\section{- Sociocultural Adaptation Scale (SCAS)}

The Socio-Cultural Adaptation Scale (SCAS) was developed by Searle and Ward in 1990. The SCAS was designed to measure the cognitive and behavioral dimensions of individual social and cultural adaptation. The scale consists of 41 items and this scale has a range from 1 (no difficulty) to 5 (extreme difficulty). Lower scores indicate less difficulty and stronger socio-cultural adaptation. Previous studies reported SCAS had a Cronbach's alpha value of .91 (Klemens \& Bikos, 2009) and .88 for result of Wilson, Ward, and Fischer's research (2013).

- Ryff's Psychological Well-Being Scale (RPWB)

The measure of psychological well-being in this study used the Ryff's scale. Ryff's Psychological Well-Being Scale (RPWB) is a survey instrument developed by Carol Ryff in 1989 and it has 42 question items. This scale uses 6 response options on a Likert scale, namely: (1) Strongly disagree, (2) Disagree, (3) Quite disagree, (4) Quite agree, (5) Agree, and (6) Strongly agree. This Ryff scale measure had been tested by several Western researchers, such as studies with a Cronbach's alpha of .80 (Abbott, Croudace, Huppert, Kuh, Ploubidis, \& Wadsworth, 2006; Springer \& Hauser, 2006; Van Dierendonck, 2004). However, in Asian studies (for example in Malaysia) these 42 items had the result for the Cronbach's alpha values of .75 (Nor Ezdianie Omar, 2009), .70 (Wan Norhayati Wan Othman, 2014) and .82 (Farah Hidayah Hashim \& Wan Norhayati Wan Othman, 2015).

\section{Procedure}

Before collecting the data, the approval of the ethical committee was gathered such obtain written permission from the university, and then the researchers must seek permission from the scholarship institution to conduct the study by recruiting its students as respondents. Furthermore, informed consent must be read in advance by the study respondents before starting the study to ensure they know and understand that they are given the appropriate protection rights in this study.

\section{RESULTS}

In the study, researchers have used SPSS and SmartPLS 3.0 software to analyze the data because it was suitable for answering the research questions. Based on the theory of Hair, Ringle, and Sarstedt (2013), they said that if the purpose of research is exploratory so researchers should use PLS-SEM. When analyzing the data, researchers have followed analytical procedures as suggested by Hair, Hult, Ringle, and Sarstedt (2017). In this study, the 


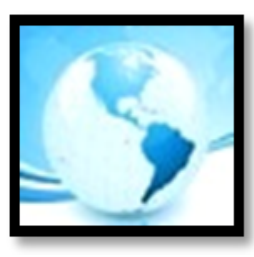

\section{MALAYSIAN ONLINE JOURNAL OF EDUCATIONAL MANAGEMENT (MOJEM)}

researchers analyzed the measurement model and then proceed to analyze the structural model, this step to ensure that the measures used in the study were reliable and valid to answer the research questions.

- Multicollinearity Analysis

The findings of the collinearity study showed the results of multicollinearity analysis using VIF and tolerance analysis. According to theories of Hair et al. (2017) about multicollinearity, they stated that multicollinearity problems exist when the VIF value exceeds 5.0 and the tolerance value is less than 0.2 . The results obtained in this study indicated that the finding was free of multicollinearity problem because the VIF value was less than 5 . Therefore, the collinearity analysis results in this study did not have a problem.

- Internal Reliability and Convergent Validity

The measurement model refers to the relationship between measures and their constructs (Jarvis, MacKenzie, \& Podsakoff, 2003). Further, the validity of measurement model can be done in two ways: convergent validity and discriminant validity. Convergent validity is assessed through factor loading, composite reliability (CR) and average variance extracted (AVE), while discriminant validity is evaluated, by comparing the square root of AVE with the correlation between the variables (Hair, Hult, Ringle, \& Sarstedt, 2017). Hair et al. (2017) recommended that a composite reliability (CR) of 0.70 or above and an average variance extracted (AVE) of more than 0.50 are considered acceptable.

The results of Confirmatory Factor Analysis (CFA) obtained in this study can be seen that there were several subconstructs that showed CR values were above 0.70 and AVE were above 0.50 and some of them were less than 0.70 for CR and 0.50 for AVE. Sub-constructs that had a CR value above 0.70 and AVE above 0.50 can be concluded that the convergent validity for the measurement model on the sub-construct has been fulfilled.

Table 1

CFA result for measurement model

\begin{tabular}{|c|c|c|c|c|c|}
\hline \multirow{2}{*}{$\begin{array}{l}\text { Second } \\
\text { Construct }\end{array}$} & & \multirow[t]{2}{*}{ First Order Construct } & \multirow{2}{*}{$\begin{array}{l}\text { Internal Reliability } \\
\text { (Cronbach Alpha) }\end{array}$} & \multicolumn{2}{|c|}{ Convergent Validity } \\
\hline & & & & CR & AVE \\
\hline \multirow{2}{*}{$\begin{array}{l}\text { Academic stress } \\
\text { (ASS) }\end{array}$} & & Psychosocial stress (SPK) & 0.908 & 0.925 & 0.580 \\
\hline & & Psychological stress (SPS) & 0.958 & 0.962 & 0.614 \\
\hline \multirow[t]{5}{*}{ Coping (COPE) } & PFC & Active coping (PFC1) & 0.718 & 0.826 & 0.543 \\
\hline & & Planning (PFC2) & 0.769 & 0.853 & 0.593 \\
\hline & & $\begin{array}{l}\text { Suppression of competing for } \\
\text { activities (PFC3) }\end{array}$ & 0.738 & 0.836 & 0.561 \\
\hline & & Restraint (PFC4) & 0.752 & 0.842 & 0.572 \\
\hline & & $\begin{array}{l}\text { Use of instrumental social } \\
\text { support (PFC5) }\end{array}$ & 0.803 & 0.871 & 0.628 \\
\hline \multirow{3}{*}{$\begin{array}{l}\text { Socio-cultural } \\
\text { adaptation (SCAS) }\end{array}$} & & Making friends (AKB) & 0.939 & 0.948 & 0.648 \\
\hline & & $\begin{array}{l}\text { Participating in social gatherings } \\
\text { (APS) }\end{array}$ & 0.953 & 0.959 & 0.556 \\
\hline & & $\begin{array}{l}\text { Communicating with host } \\
\text { nationals (AKW) }\end{array}$ & 0.899 & 0.919 & 0.588 \\
\hline \multirow{3}{*}{\multicolumn{2}{|c|}{$\begin{array}{l}\text { Psychological } \\
\text { well-being (PWB) }\end{array}$}} & Autonomy (KPA) & 0.883 & 0.912 & 0.633 \\
\hline & & Self-acceptance (KPK) & 0.860 & 0.896 & 0.589 \\
\hline & & Purpose in life (KPT) & 0.895 & 0.920 & 0.656 \\
\hline
\end{tabular}




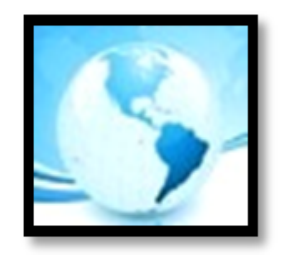

\section{MALAYSIAN ONLINE JOURNAL OF \\ EDUCATIONAL MANAGEMENT \\ (MOJEM)}

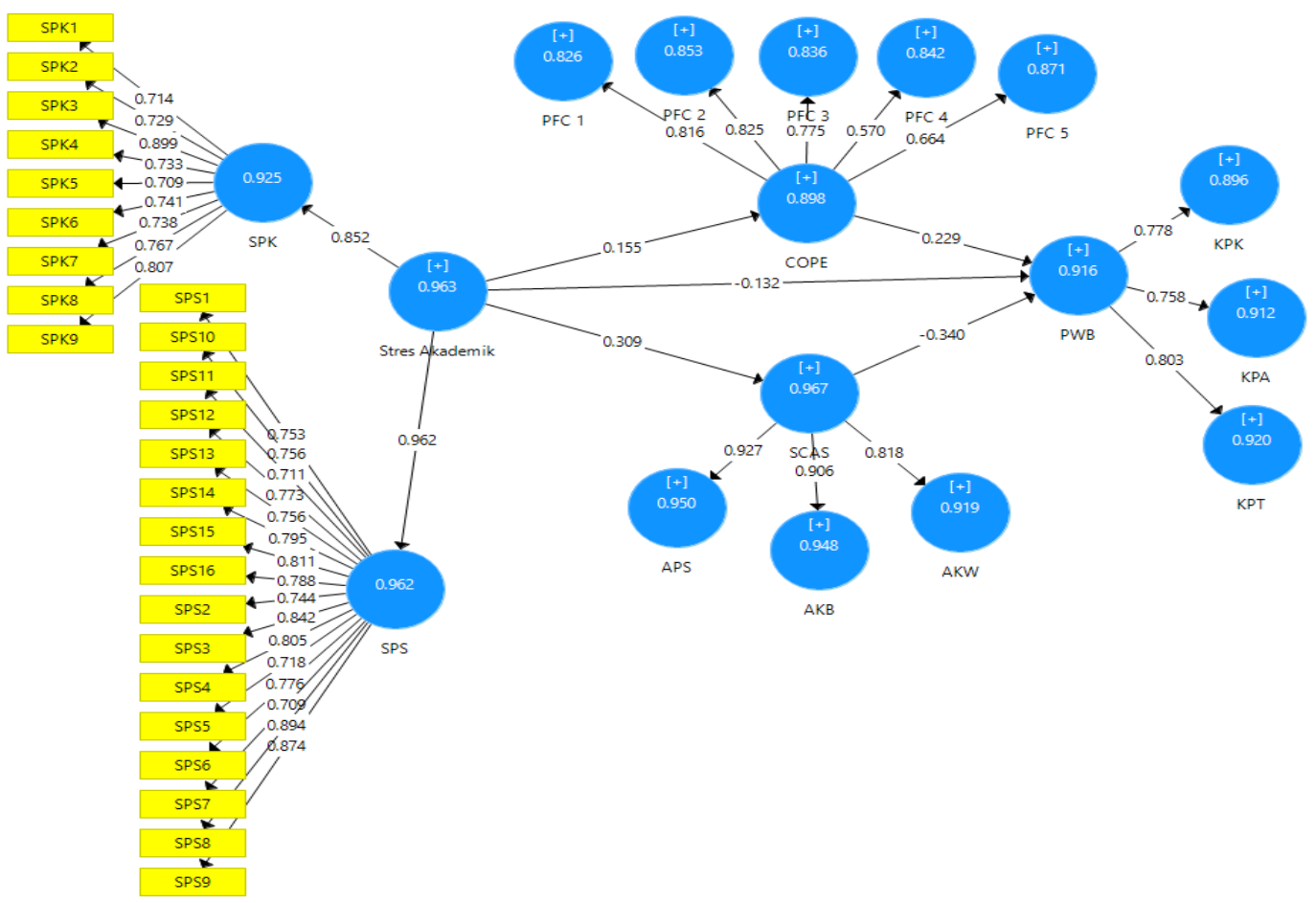

Figure 2. Convergence validity of academic stress

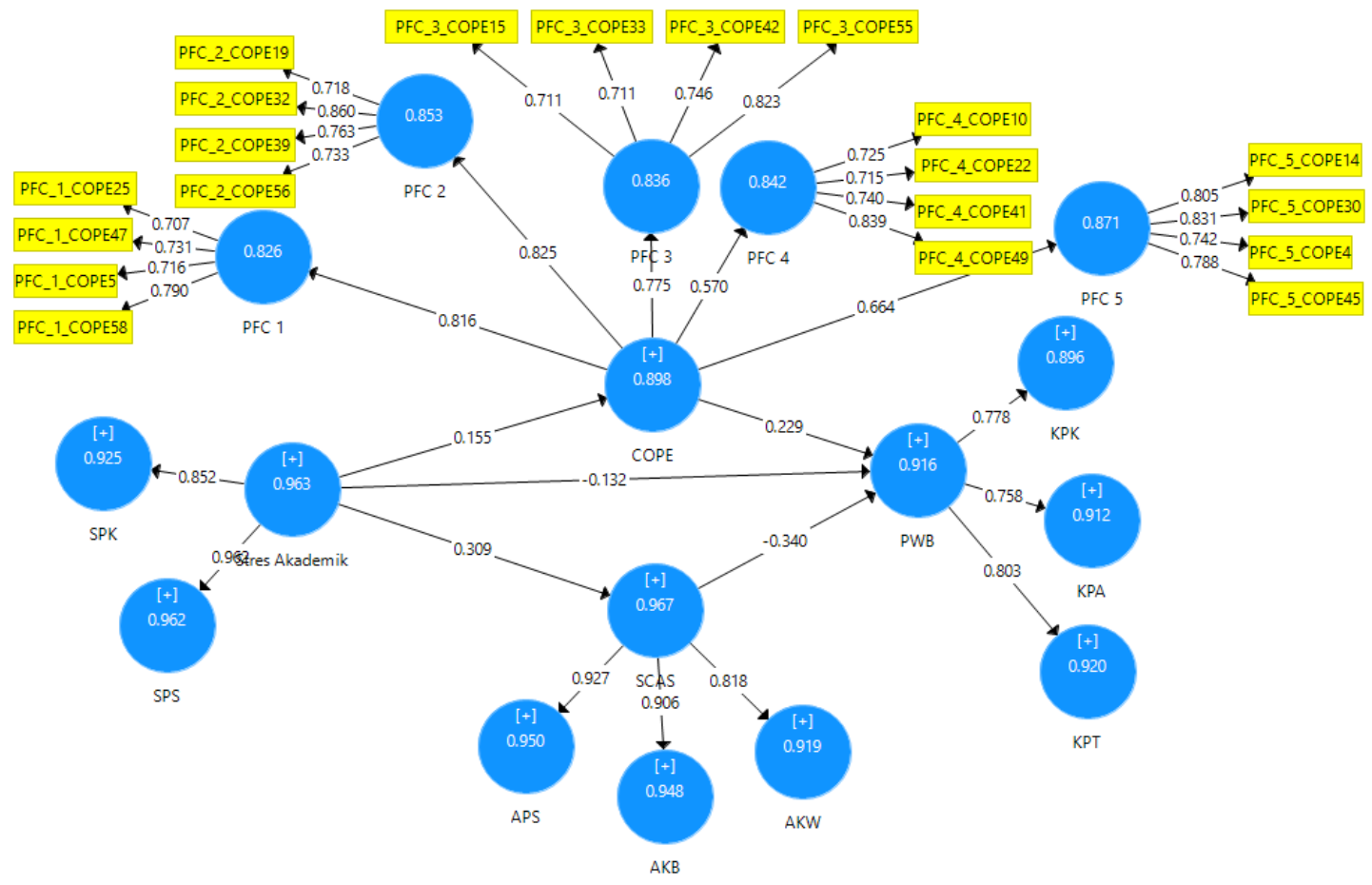

Figure 3. Convergence validity of coping PFC 


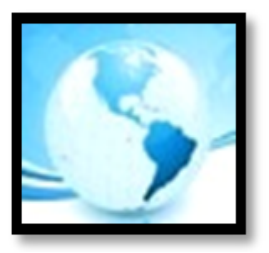

MALAYSIAN ONLINE JOURNAL OF

EDUCATIONAL MANAGEMENT

(MOJEM)

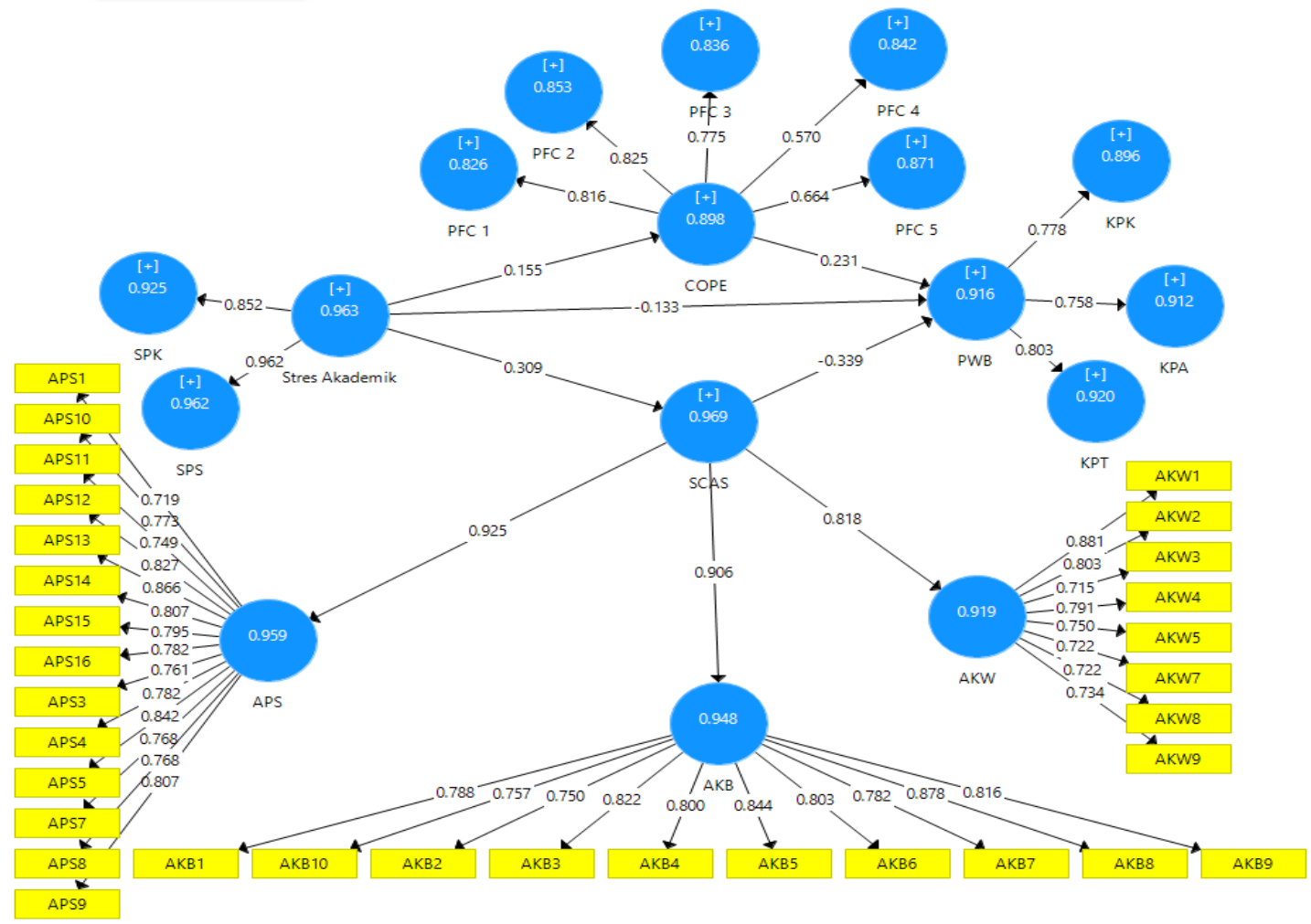

Figure 4. Convergence validity of socio-cultural adaptation (SCAS)

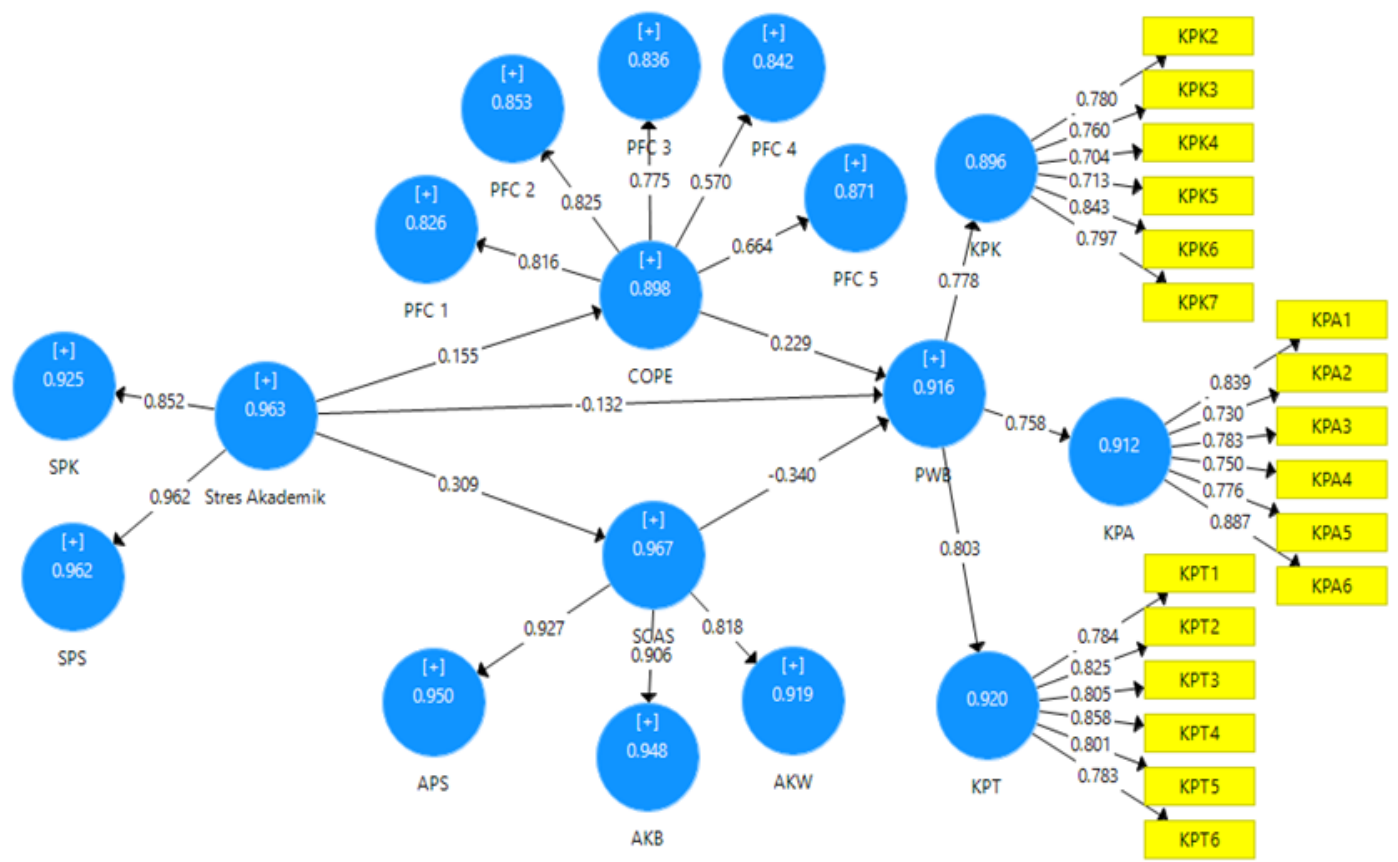

Figure 5. Convergence validity of psychological well-being (PWB) 


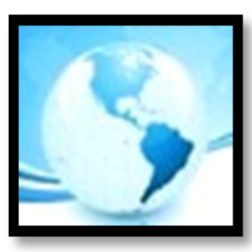

- Discriminant validity

After testing the convergent validity, researchers also need to consider of discriminant validity in order to make sure the items that used to measure a certain construct are different with other construct in the model. The Fornell-Larcker criterion (Hair et al., 2013) is one of to assess the discriminant validity. According to Fornell and Larcker (1981) discriminant validity can be established by calculating the square root of the AVE. The square root of each construct's AVE should be greater than its highest correlation with any other construct (Hair et al., 2013). However, Hair et al. (2017) stated discriminant validity also can be established by assessing the cross loading and heterotrait-monotrait ratio of correlations (HTMT) value. Anyhow, for this paper, researchers were only used square root of the AVE to assess the discriminant validity.

Table 2

The results of Fornell-Larcker criterion

\begin{tabular}{|c|c|c|c|c|c|c|c|c|c|c|c|c|c|c|c|c|c|}
\hline & AKB & AKW & APS & COPE & KPA & KPK & KPT & PFC 1 & PFC 2 & PFC 3 & PFC 4 & PFC 5 & PWB & SCAS & SPK & SPS & SA \\
\hline$A K B$ & 0.805 & & & & & & & & & & & & & & & & \\
\hline$A K T V$ & 0.676 & 0.767 & & & & & & & & & & & & & & & \\
\hline APS & 0.736 & 0.632 & 0.790 & & & & & & & & & & & & & & \\
\hline COPE & -0.056 & -0.081 & -0.071 & 0.737 & & & & & & & & & & & & & \\
\hline KPA & -0.321 & -0.402 & -0.266 & 0.083 & 0.796 & & & & & & & & & & & & \\
\hline KPK & -0.296 & -0.381 & -0.278 & 0.201 & 0.390 & 0.768 & & & & & & & & & & & \\
\hline KPT & -0.199 & -0.256 & -0.201 & 0.262 & 0.393 & 0.453 & 0.810 & & & & & & & & & & \\
\hline PFC 1 & -0.096 & -0.109 & -0.108 & 0.816 & 0.136 & 0.191 & 0.229 & 0.737 & & & & & & & & & \\
\hline PFC 2 & -0.091 & -0.120 & -0.110 & 0.825 & 0.160 & 0.218 & 0.361 & 0.636 & 0.770 & & & & & & & & \\
\hline $\mathrm{PFC} 3_{3}$ & -0.028 & -0.049 & -0.006 & 0.775 & -0.012 & 0.099 & 0.183 & 0.542 & 0.556 & 0.749 & & & & & & & \\
\hline $\mathrm{PFC} 4_{4}$ & 0.089 & 0.064 & 0.066 & 0.570 & -0.006 & 0.080 & 0.047 & 0.316 & 0.350 & 0.340 & 0.756 & & & & & & \\
\hline PFC 5 & -0.038 & -0.041 & -0.065 & 0.664 & -0.011 & 0.127 & 0.080 & 0.433 & 0.387 & 0.371 & 0.265 & 0.792 & & & & & \\
\hline PWB & -0.346 & -0.441 & -0.316 & 0.236 & 0.758 & 0.778 & 0.803 & 0.240 & 0.320 & 0.119 & 0.052 & 0.084 & 0.780 & & & & \\
\hline SCAS & 0.906 & 0.818 & 0.925 & -0.079 & -0.353 & -0.346 & -0.240 & -0.120 & -0.122 & -0.028 & 0.082 & -0.058 & -0.399 & 0.885 & & & \\
\hline SPK & 0.266 & 0.238 & 0.212 & 0.124 & -0.259 & -0.148 & -0.144 & 0.052 & 0.036 & 0.113 & 0.182 & 0.112 & -0.234 & 0.266 & 0.762 & & \\
\hline SPS & 0.323 & 0.246 & 0.228 & 0.153 & -0.200 & -0.155 & -0.028 & 0.073 & 0.071 & 0.112 & 0.106 & 0.218 & -0.160 & 0.295 & 0.675 & 0.783 & \\
\hline SA & 0.329 & 0.264 & 0.241 & 0.155 & -0.239 & -0.166 & -0.074 & 0.071 & 0.064 & 0.122 & 0.143 & 0.196 & -0.202 & 0.309 & 0.852 & 0.962 & 0.909 \\
\hline
\end{tabular}

- Hypothesis Testing

Table 3

Summary of hypothesis tests

\begin{tabular}{|c|c|c|c|c|c|}
\hline Hypothesis & $\begin{array}{l}\text { Standardized } \\
\text { Coefficients }(\boldsymbol{\beta})\end{array}$ & Path & T-value & P-value & Significant Levels \\
\hline$S A->$ PWB & -0.133 & & 2.851 & 0.004 & $<0.05$ \\
\hline COPE $->$ PWB & 0.231 & & 4.482 & 0.000 & $<0.001$ \\
\hline SCAS -> PWB & -0.339 & & 6.672 & 0.000 & $<0.001$ \\
\hline SA $->$ COPE & 0.155 & & 3.047 & 0.002 & $<0.05$ \\
\hline SA $->$ SCAS & 0.309 & & 6.991 & 0.000 & $<0.001$ \\
\hline
\end{tabular}




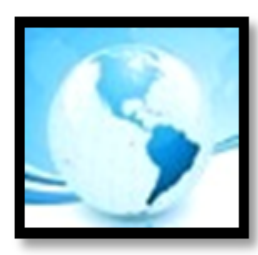

MALAYSIAN ONLINE JOURNAL OF

EDUCATIONAL MANAGEMENT

(MOJEM)

Table 4

Analysis Results of R-square dan F-square

\begin{tabular}{|c|c|c|c|c|}
\hline Endogenous Variables & Exogenous Variables & $R^{2}$ Included & $R^{2}$ Excluded & $f^{2}$ \\
\hline \multirow{3}{*}{$\begin{array}{l}\text { Psychological } \\
\text { (PWB) }\end{array}$} & Academic Stress & \multirow{3}{*}{0.216} & 0.202 & 0.019 \\
\hline & Cope & & 0.167 & 0.064 \\
\hline & $\begin{array}{l}\text { Socio-Cultural } \\
\text { Adaptation }\end{array}$ & & 0.114 & 0.132 \\
\hline
\end{tabular}

The results showed that, (1) Academic stress had a negative effect on psychological well-being $[\beta=-0.133, t=2.851$, $p<0.05]$; (2) Coping had a positive effect on psychological well-being $[\beta=0.231, t=4.482, p<0.001]$; (3) Socio-Cultural adaptation had a negative effect on psychological well-being $[\beta=-0.339, t=6.672, p<0.001]$; (4) Academic stress had a positive effect on coping $[\beta=0.155, t=3.047, p<0.05]$; and finally (5) Academic stress had a positive effect on socio-cultural adaptation $[\beta=0.309, t=6.991, p<0.001]$. Therefore, the results answered research question number 1 and indicated that academic stress, coping and social cultural adaptation have a significant effect on the psychological well-being. Then, for research question number 2 and represented that academic stress has a significant effect on coping and social cultural adaptation.

\section{DISCUSSION}

The findings from the hypotheses testing for the first research question implied that there is a significant effect of academic stress, coping and social cultural adaptation on the psychological well-being among postgraduate students sponsored by Indonesian education. This finding corresponded with the evidence presented by KormiNouri, Macdonald, Farahani, Trost, and Shokri (2015) said that academic stress came from internal and external problems, such as interactions with faculty and university staff, managing various non-academic factors (work, family obligations, and leisure time). Other previous study also described stress among students which involved academic, social, financial, daily complexity, and family relationships (Brougham, Zail, Mendoza, \& Miller, 2009). Thus, stress is an individual's interpretation of the relationship between people and the environment, yet individuals value the situation beyond their personal resources and abilities and can jeopardize their well-being (Aihie \& Ohanaka, 2019; Michaela, Pascoe, Hetrick, \& Parker, 2019).

The findings from the second research question indicated that academic stress has a significant effect on coping and social cultural adaptation. The earlier studies showed an effective relationship between academic stress and coping among various academic disciplines and population of university. Difficulty in coping of stress and controlling aspects of stress caused by college life can lead to tense, health problems and academic failure (Pizzolato, 2004; Selye, 1991; Smith, 2019; Taylor \& Stanton, 2007). Therefore, students need to be assisted with different strategies to improve their ability to withstand all stress or pressure in their academic experiences. The strategy required is the strategy to deal with the stress that they experienced and it is commonly referred coping (Brougham et al., 2009). Coping with stress is an important factor, it influences whether and how individuals seek medical care and social support and follow professional advice (Wolf \& Boama, 2018). Some previous studies have found that new university students who have just started their education in a new place but they must face the challenges, some of them have language problems such as inadequate linguistic skills, homesickness and loneliness (Cecen, 2008; Thomas, 2018; Thurber \& Walton, 2012).

\section{IMPLICATIONS}

The result of this study indicates that the academic stress, coping and socio-cultural adaptation have a significant effect on the psychological well-being of Indonesian students. So, the results of this study also have implications for other related parties (such as management of higher education, university student affairs professionals and top 


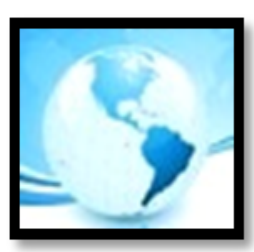

\section{MALAYSIAN ONLINE JOURNAL OF EDUCATIONAL MANAGEMENT (MOJEM)}

management of university) to focus more deeply on the major component of the educational process such the role of the lecturers in educating students, giving a task, and building healthy relationships with students. Therefore, the current findings will help professional counselors, educators, policymakers to improve the education management system in order to reduce cases of academic stress on university students. Thus, this can help to realize the psychological well-being of students at the university. As we know that educating a person is the process of training and the transformation of the individual.

\section{CONCLUSIONS}

To summarize, after the preliminary study has been carried out, the results were as follows: the constructs of academic stress were divided into two namely psychosocial stress (SPK) and psychological stress (SPS). Moreover, the findings of this study indicated that the students in this study encountered academic stress related to final grade, excessive homework, term papers, examinations, studying for examinations, waiting for graded tests, pop quizzes, forgotten assignments, incomplete assignments, unclear assignments, announced quizzes, missing class, unclear course objectives, attending wrong class, late dismissals of class, and arriving late for class. Those academic stresses are categorized into the psychological stress by Kohn and Frazer (1986). Whereas the categories of psychosocial stress are class speaking, fast-paced lectures, unprepared to respond to questions, incorrect answers in class, learning new skills, nonnative language lectures, boring classes, note-taking in class, and evaluating classmates' work (Kohn \& Frazer, 1986).

Next, the second construct was coping. Coping or COPE was found one sub-construct, which was problem-focused coping (PFC) which included active coping (PFC1), planning (PFC2), suppression of competing for activities (PFC3), restraint (PFC4) and use of instrumental social support (PFC5). Furthermore, the coping that is used by respondents in this study is problem-focused coping (PFC). PFC is controlled and reduced stress by solving the problem with changing the environment. This coping is considered to be a positively oriented approach or a positive reinforcement style and in line with lower levels of stress (Jones \& Johnston, 1997; Gibbons, 2010; Shikai, Shono, Kitamura, \& Masahiro, 2009).

Further on, the third construct was a socio-cultural adaptation that consisted of three sub-constructs. Those were making friends (AKB), participating in social gatherings (APS), and communicating with host nationals (AKW). Then, there are three skills of Indonesian students in adapting to the social and cultural context of this study, such as being good at making new friends, active in social gatherings and skilled in communicating with the host country. Being good at making new friends is like being good at dealing with someone uncomfortable or aggressive. Being active in social gatherings is like going to social events or gatherings, and the last one is good at communicating with the host country. Being able to communicate with the host country is as good as communicating with people from different ethnic groups.

last construct was psychological well-being (PWB) which was divided into three sub-constructs namely autonomy (KPA), self-acceptance (KPK) and purpose in life (KPT). There are three dimensions influenced the psychological well-being of the respondents; the first one is the sense of self-determination, independence, and freedom from norms or commonly referred to as autonomy. Further, the second dimension is a positive attitude toward oneself and a past life or it referred to as self-acceptance and lastly, the third one is a living goal and belief that one's life is meaningful or known by the purpose in life.

Thus, the findings of this study provided some suggestions for future researchers, one of them is to conduct the same research but with different study designs such as a qualitative research design. It is hoped that with the qualitative method, researchers can further explore deeper the academic problems faced by students and how students can control their academic stress and how they adapt to their new environment. Hopefully, the results of this quantitative study can significantly contribute to the management of higher education, educators and 


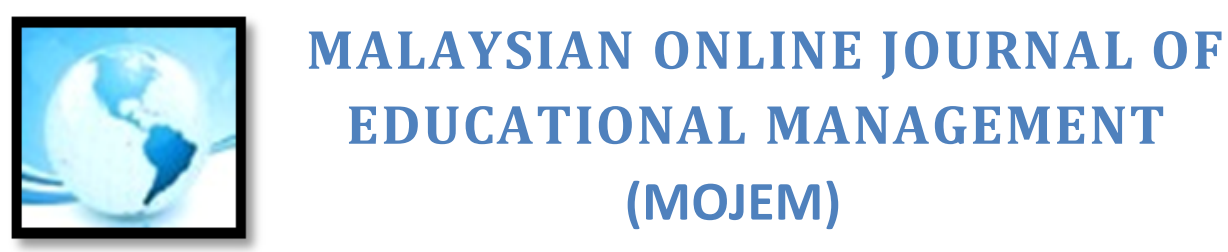

professional counselors to pay more attention to the issue of academic stress experienced by postgraduate university students.

\section{ACKNOWLEDGMENTS}

This study was funded by from Indonesia Endowment Fund for Education (LPDP, https://www.Ipdp.kemenkeu.go.id/). The sponsor has no role in the study design, data collection and analysis, decision to publish, or preparation of the manuscript.

Conflict of interest: The authors declare that there is no conflict of interests

\section{REFERENCES}

Abbott, R. A., Croudace, T. J., Huppert, F. A., Kuh, D., Ploubidis, G. B., \& Wadsworth, M. E. J. (2006). Psychometric evaluation and predictive validity of Ryff's Psychological Well-Being items in a UK Birth Cohort sample of women. Health \& Quality of Life Outcomes, 4, 76-16. doi: 10.1186/1477-7525-4-76.

Aihie, O. N., \& Ohanaka, B. I. (2019). Perceived academic stress among undergraduate students in a Nigerian University. Journal of Educational and Social Research, 9(2), 2240-0524. Doi: 10.2478/jesr-2019-0013

Andrews, B., \& Wilding, J. M. (2004). The relation of depression and anxiety to life-stress and achievement in students. British Journal of Psychology, 95, 509-521.

Aselton, P. (2012). Sources of stress and coping in American college students who have been diagnosed with depression. Journal of Child and Adolescent Psychiatric Nursing, 25(3), 119-123.

Badan Pusat Statistik. (2017). Jumlah Perguruan Tinggi, Mahasiswa, dan Tenaga Edukatif (Negeri dan Swasta) di Bawah Kementrian Pendidikan dan Kebudayaan Menurut Provinsi 2013/2014-2014/2015 [Number of Universities, Students and Educational Staff (Public and Private) Under the Ministry of Education and Culture by Province 2013 / 2014-2014 / 2015]. Retrieved from https://www.bps.go.id/statictable/2015/09/14/1839/jumlah-perguruan-tinggi-mahasiswa-dan-tenagaedukatif-negeri-dan-swasta-di-bawah-kementrian-pendidikan-dan-kebudayaan-menurut-provinsi-20132014-2014-2015.html

Borrello, A. (2005). Subjective well-being and academic success among college students (Doctoral dissertation). Capella University. Dissertation Abstracts International, 66(05), 2810B (Publication No. AAT 3174525). Retrieved from Dissertation Abstracts Online.

Burnett, P. C., \& Fanshawe, J. P. (1997). Measuring school-related stressors in adolescents. Journal of Youth and Adolescence, 26, 415-428.

Brougham, R. R., Zail, C. M., Mendoza, C. M., \& Miller, J. B. (2009). Stress, sex differences, and coping strategies among college students. Current Psychology, 28, 85-97.

Carter, J. S., Garber, J., Ciesla, J. A., \& Cole, D. A. (2006). Modeling relations between hassles and internalizing and externalizing symptoms in adolescents: A four-year prospective study. Journal of Abnormal Psychology, 1153, 428-442. Retrieved from https://www.ncbi.nlm.nih.gov/pubmed/16866584

Carver, C. S., Scheier, M. F., \& Weintraub, J. K. (1989). Assessing coping strategies: A theoretically based approach. Journal of Personality and Social Psychology, 56, 267-283.

Cecen, A. (2008). The effects of gender and loneliness levels on ways of coping among university students. College Student Journal, 42(2), 510-516.

Desmita. (2009). Perkembangan peserta didik [Student development]. Bandung: PT Remaja Rosdakarya.

Diehl, M., \& Hay, E. L. (2011). Self-concept differentiation and self-concept clarity across adulthood: Associations with age and psychological well-being. The International Journal of Aging \& Human Development, 73(2), 125-152.

Dzokoto, V., Hicks, T., \& Miller, E. (2007). Student lifestyles and emotional well-being at a historically black university. Education, 127, 511-522. 


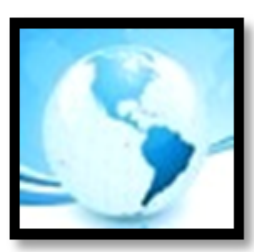

\section{MALAYSIAN ONLINE JOURNAL OF EDUCATIONAL MANAGEMENT (MOJEM)}

Farah Hidayah Hashim, \& Wan Norhayati Wan Othman. (2015). Hubungan efikasi kendiri dengan kesejahteraan psikologi pelajar ljazah Sarjana Muda Psikologi semester akhir [Self-efficacy relationship with psychological well-being of Bachelor of Psychology final semester students]. Jurnal IImi, 5(5), 25-36.

Feld, L. D. (2011). Student stress in high-pressure college preparatory schools. Applied Cognitive Psychology, 35, 701-710. Retrieved from http://wesscholar.wesleyan.edu/etd_hon_theses/685

Fornell, C., \& Larcker, D. F. (1981). Evaluating Structural Equation Models with Unobservable Variables and Measurement Error. Journal of Marketing Research, 18(1), 39. http://doi.org/10.2307/3151312

Friedlander, L. J., Reid, G. J., Shupak, N., \& Cribbie, R. (2010). Social support, selfesteem and stress as predictors of adjustment to university among first- year undergraduates. Journal of College Student Development, 46(3), 223-236.

Gibbons. (2010). Stress, coping and burn-out in nursing students. International Journal Nurse Student, 47(10):1299309. doi: 10.1016/j.ijnurstu.2010.02.015.

Greer, T. M., \& Brown, P. (2011). Minority status stress and coping processes among African American college students. Journal of Diversity in Higher Education, 4, 26-38.

Hair, J. F., Ringle, C. M., \& Sarstedt, M. (2013). Editorial-partial least squares structural equation modeling: Rigorous applications, better results and higher acceptance. Long Range Planning, 46(1-2), 1-12.

Hair, J. F., Hult, G. T. M., Ringle, C. M., \& Sarstedt, M. (2017). A primer on partial least squares structural equation modeling (PLS-SEM) (2nd ed.). Los Angeles: Sage Publications.

Harikiran, A., Srinagesh, J., \& Nagesh, K. (2012) Perceived sources of stress amongst final year dental under graduate students in a dental teaching institution at Bangalore, India: A cross sectional study. Indian Journal of Dental Research, 23, 331-336.

Hoggard, L., Byrd, C., \& Sellers, R. (2012). Comparison of African American college students' coping with racially and non-racially stressful events. Cultural Diversity and Ethnic Minority Psychology, 18, 329-339.

Huriatul Masdar, Pragita Ayu Saputri, Dani Rosdiana, Fifia Chandra, \& Darmawi (2016). Depresi, ansietas, dan stres serta hubungannya dengan obesitas pada remaja [Depression, anxiety, and stress and its relationship with obesity in adolescents]. Jurnal Gizi Klinik Indonesia, 12(4), 138-143.

Suwartika, I., Nurdin, A., \& Ruhmadi, E. (2014). Analisis faktor yang berhubungan dengan tingkat stress akademik mahasiswa reguler program studi D III Keperawatan Cirebon Poltekkes Kemenkes Tasikmalaya [Factor analysis related to regular student academic stress level study III Nursing Programme Cirebon Poltekkes Kemenkes Tasikmalaya]. Jurnal Keperawatan Soedirman, 9(3), 173-189.

Jarvis, C. B., MacKenzie, S. B., \& Podsakoff, P. M. (2003). A critical review of construct indicators and measurement model misspecification in marketing and consumer research. Journal of Consumer Research, 30(2), $199-218$.

Jdaitawi, M. (2015). Social Connectedness, Academic, Non-academic behaviors related to self-regulation among university students in Saudi Arabia. International Education Studies, 8(2), -- doi:10.5539/ies.v8n2p84.

Jones, M. C., \& Johnston, D. W. (1997). Distress, stress and coping in first-year student nurses. Journal of Advanced Nursing, 26, 475-482. https://doi.org/10.1046/j.1365-2648.1997.t01-5-00999.x

Johnson, B., \& Christensen, L. (2008). Educational Research: Quantitative, qualitative and mixed method approaches ( $3^{\text {rd }}$ ed.). United States: Sage Publication.

Kadapatti, M., \& Vijayalaxmi, A. H. M. (2012). Stressors of academic stress: A study on preuniversity students. Indian Journal of Scientific Research, 3(1), 171-175.

Kohn, J. P., \& Frazer, G. H. (1986). An academic stress scale: Identification and rated importance of academic stressors. Psychological Reports, 59(2), 415-426.

Kormi-Nouri, R., MacDonald, S., Farahani, M. N., Trost, K., \& Shorki, O. (2015). Academic stress as a health measure and its relationship to patterns of emotion in collectivist and individualist cultures: Similarities and differences. International Journal of Higher Education, 4(2), 92.

Klemens, M. J., \& Bikos, L. H. (2009). Psychological well-being and sociocultural adaptation in college-aged, repatriated, missionary kids. Mental Health, Religion \& Culture, 12(7), 721-733. doi:10.1080/13674670903032629

Lazarus, R. S. (1966). Psychological stress and the coping process. Monterey, CA: Brooks/Cole Publishing Company. 


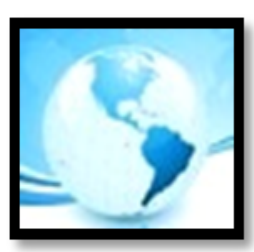

MALAYSIAN ONLINE JOURNAL OF

EDUCATIONAL MANAGEMENT

(MOJEM)

Lazarus, R., \& Folkman, S. (1984). Stress, appraisal, and coping. New York, NY: Springer.

Litman, J. A. (2006). The COPE inventory: Dimensionality and relationships with approach- and avoidance-motives and positive and negative traits. Personality and Individual Differences, 41, 273-284.

Lyubomirsky, S., King, L., \& Diener, E. (2005). The benefits of frequent positive affect: Does happiness lead to success? Psychological Bulletin, 131(6), 803-855.

Michaela, C., Pascoe, M. C., Hetrick, S. E., \& Parker, A. G. (2019). The impact of stress on students in secondary school and higher education. International Journal of Adolescence and Youth, 25(1), 2164-4527. doi: 10.1080/02673843.2019.1596823

Mitchell, C. V. (2016). Assessing the validity and reliability of the Mitchell coping skills inventory in a college population (Unpublished Doctoral Thesis). The School of Psychology, Spalding University, Louisville, Kentucky.

Myhren, H., Ekeberg, O., \& Stokland, O. (2013). Job satisfaction and burnout among intensive care nurses and physicians. Critical Care Research and Practice, 2013. doi: http://dx.doi.org/10.1155/2013/786176

Natovova, L., \& Chylova, H. (2014). Is there a relationship between self-efficacy, well-being and behavioural markers in managing stress at university students? Journal on Efficiency and Responsibility in Education and Science, $7(1), 14-18$.

Nor Ezdianie Omar. (2009). Kesejahteraan psikologi dalam kalangan pelajas IPTS [Psychological well-being among university students]. Jurnal Pendidikan dan Latihan, 1(2), 1-11.

Pizzolato, J. (2004). Coping with conflict: Self-authorship, coping, and adaptation to college in first-year, high-risk students. Journal of College Student Development, 45, 425-442.

Rice, K. G., \& Van Arsdale, A. C. (2010). Perfectionism, perceived stress, drinking to cope, and alcohol-related problems among college students. Journal of Counseling Psychology, 57(4), 439-450. doi:10.1037/a0020221

Romas, J. A., \& Sharma, M. (2004). Practical stress management: A comprehensive workbook for managing health and promoting health. (3rd edition). Pearson: Benjamin Cummings.

Ryff, C. D. (1989). Happiness is everything, or is it? Explorations on the meaning of psychological well-being. Journal of Personality and Social Psychology, 57(6), 1069-1081. http://dx.doi.org/10.1037/00223514.57.6.1069

Sansgiry, S., \& Sail, K. (2006) Effect of students' perceptions of course load on test anxiety. American Journal of Pharmaceutical Education, 70(2), 26.

Sagone, E., \& De Caroli, M. E. (2014), A correlational study on dispositional resilience, psychological well-being, and coping strategies in university students. American Journal of Educational Research, 2(7), 463-471.

Searle, W., \& Ward, C. (1990). The prediction of psychological and sociocultural adjustment during cross-cultural transitions. International Journal of Intercultural Relations, 14, 449-464.

Shikai, N., Shono, M., Kitamura, T., \& Masahiro. (2009). Effects of coping styles and stressful life events on depression and anxiety in Japanese nursing students: A longitudinal study. International Journal of Nursing Practice. 15(3),198 - 204. doi:10.1111/j.1440-172X.2009.01745.x

Smith, A. P. (2019). Smoking, alcohol, wellbeing and academic attainment. Journal of Health and Medical Sciences, 2(3), 337-343. doi: 10.31014/aior.1994.02.03.55

Somerfield, M. R., \& McCrae, R. R. (2000). Stress and coping research: Methodological challenges, theoretical advances, and clinical applications. American Psychologist, 55(6), 620-5.

Springer, K. W., \& Hauser, R. M. (2006). An assessment of the construct validity of Ryff's scales of psychological well-being: Method, mode, and measurement effects. Forthcoming in Social Science Research, 35, 10801102.

Sri Nurhayati Selian \& Siti Rafiah Abdul Hamid. (2016). Exploring the psychological well-being and coping strategies of terminally ill cancer patients: as Indonesian case study. In: Spirituality, Religion and Coping: Studies on Psychological Well-Being from Educational Perspective (pp. 287-337). Kuala Lumpur: Institut Terjemahan \& Buku Malaysia Berhad.

Suriani, Abdul Hamid \& Suraini, Mohd Rhouse. (2005, 30 July). Punca tekanan pelajar di universiti: Satu perbandingan antara gender [Causes of university students' stress: A comparison between genders]. Paper presented at Prasidang Persidangan Psikologi Malaysia, Hotel Promenade, Kota Kinabalu. 
Taylor, S. E., \& Stanton, A. L. (2007). Coping resources, coping processes, and mental health. The Annual Review of Clinical Psychology, 3, 377-401. doi: 10.1146/annurev.clinpsy.3.022806.091520

Thomas, D. (2018). Factors that contribute to homesickness among students in Thailand. Kasetsart Journal of Social Sciences, $x x x$, 1-6. https://doi.org/10.1016/j.kjss.2018.07.011

Thurber, C., \& Walton, E. (2012). Homesickness and adjustment in university students. Journal of American College Health, 6, 1- 5 .

Triantoro, S. (2006). Stres ditinjau dari active coping, avoidance coping dan negative coping. Humanitas, 3(2), 8793.

Van Dierendonck, D. (2004). The construct validity of Ryff's Scales of Psychological Well-Being and its extension with spiritual well-being. Personality and Individual Differences, 36(3), 629-643. doi: 10.1016/S01918869(03)00122-3.

Wan Norhayati Wan Othman. (2014). Faktor yang mempengaruhi kesejahteraan psikologi Anggota Tentera Darat Malaysia [Factors affecting the psychological well-being of the Malaysian Army] (Unpublished Doctoral thesis). University of Malaya, Kuala Lumpur, Malaysia.

Wilson, J., Ward, C., \& Fischer, R. (2013). Beyond culture learning theory: What can personality tell us about cultural competence? Journal of Cross-Cultural Psychology, 44(6), 900-927. doi:10.1177/0022022113492889

Wolf, W., \& Boama, S. A. (2018). Religious faith, academic stress, and instrumental drug use in asample of Western-African University students. Performance Enhancement \& Health, 6, 53-58. https://doi.org/10.1016/j.peh.2018.07.001

Yeh, C. J., \& Inose, M. (2003). International students' reported English fluency, social support satisfaction, and social connectedness as predictors of acculturative stress. Counseling and Psychology Quarterly, 16, 15-28.

Yusoff, M. S. B., Rahim, A. F. A., \& Yaacob, M. J. (2010). Prevalence and sources of stress among Universiti Sains Malaysia medical students. The Malaysian Journal of Medical Sciences (MJMS), 17(1), 13-24. Retrieved from http://www.bioline.org.br/request?mj10006 